\title{
The Investigation of Water Quality of İyidere and Çiftekavak Streams Using Physico-Chemical and Biotic Indexes
}

\author{
Osman Serdar $^{1 *}$, Bülent Verep ${ }^{2}$ \\ I*Munzur University, Fisheries Faculty, Tunceli, Turkey, *osmanserdar@munzur.edu.tr (iD \\ ${ }^{2}$ Recep Tayyip Erdoğan University, Fisheries Faculty, Rize, Turkey, bulent.verep@erdogan.edu.tr \\ Received date: 26.02.2018, Accepted date: 25.05.2018
}

\begin{abstract}
The investigation was carried out on the Streams of Çiftekavak and İyidere in Rize between April 2010 and March 2011. Water samples were taken monthly from the station which chosen six sample points on İyidere and two sample point on Çiftekavak Stream. Water quailty was evaluated with the standard physicochemical analysis (water temperature, $\mathrm{pH}$, dissolved oxygen, oxygen saturation, electrical conductivity, suspended solid, total hardness, Ca hardness, $\mathrm{Mg}$ hardness, biological oxygen demand, nitrite nitrogen, total phosphate) like parameters were determined according to the Inland Water Resources Criteria, Water Pollution Control Regulation. With this study, it was aimed to determine the water quality of 8 stations at İyidere and Çiftekavak Streams. It had been determined that the physicochemical data were not contaminated with İyidere grade. However, Çiftekavak Stream had been determined that the pollution be under threat at the level. Benthic macroinvertebrates were analysed and compared with the measurement of parameter. In this study, as biomarker indexes, seven different biotic index such as SI (Saprobi Index), FBI (Family Biotik Index), BMWP (Biological Monitoring Index Scores), BBI (Belgium Biotic Index), ASPT (Medium Taxon Index) and EPT (Ephemeroptera Per Taxon) taxon number were used in evaluation. During the period of this study, 27 taxas which belong to Ephemeroptera, Amphipoda, Tricladida, Coleoptera, Decapoda, Rhynchobdellida, Odonata, Diptera, Trichoptera, Plecoptera, Tubificida and Arthropoda were identified. The Ephemeroptera taxa was the highest abundance values in benthic macroinvertebrates. With this study, it was aimed to determine the water quality at 8 stations at Çiftekavak and İyidere. Both biologic and physicochemical yields were found to result in unpollution of the İyidere Stream level. However, Çiftekavak stream was found to be under the threat of pollution.
\end{abstract}

Keywords: Aquatic macroinvertebrate, Çiftekavak Stream, İyidere Stream, water quality

\section{İyidere ve Çiftekavak Dereleri Su Kalitesinin Fizikokimyasal ve Biotik İndeskler Kullanılarak İncelenmesi}

$\ddot{O} \mathbf{z}$

Bu çalışma İyidere ve Çiftekavak Dereleri (Rize) üzerinde Nisan 2010 ile Mart 2011 tarihleri arasında yürütülmüştür. İyidere Dere'sinden altı örnekleme noktası, Çiftekavak Dere'sinden iki örnekleme noktası seçilmiş ve aylık periyotlarla su örnekleri alınmıştır. Alınan su örnekleri ile derelerin fiziko-kimyasal su kaliteleri (su sıcaklığı, pH, çözünmüş oksijen, oksijen doygunluğu, elektriksel iletkenlik, askıda katı madde, toplam sertlik, Ca sertliği, Mg sertliği, biyolojik oksijen ihtiyacı, nitrit azotu, toplam fosfat) gibi parametreler Su Kirliliği Kontrol Yönetmeliği Kita İçi Su Kaynakları Kriterleri (KSKK)'ne göre belirlenmiştir. Bu çalışma ile, İyidere ve Çiftekavak Dereleri su kalitesinin belirlenmesi amaçlanmıştır. Fiziko-kimyasal verilerle İyidere Dere'sinin kirlenmediği, Çiftekavak Dere'sinin daha fazla kirlilik tehdidi altında olduğu tespit edilmiştir. Taban omurgasızlara göre değerlendirmelerde ise, SI (Saprobi İndeksi), FBI (Familya Biotik İndeksi), BMWP (Biyolojik İzleme Skor İndeksi), BBI (Belçika Biyotik İndeksi), ASPT (Ortalama Takson İndeksi), TBI (Trent Biotik İndeksi) ve EPT takson sayısı olmak üzere 7 farklı biyotik indeks kullanılmıştır. Taban büyük omurgasızlardan en baskın takım Ephemeroptera başta olmak üzere, Amphipoda, Tricladida, Coleoptera, Decapoda, Rhynchobdellida, Odonata, Diptera, Trichoptera, Plecoptera, Tubificida ve Arthropoda takımlarına ait 27 takson teşhis edilmiştir. Bu çalışma ile, Çiftekavak ve İyidere derelerinde 8 istasyonda su kalitesinin belirlenmesi amaçlanmıştır. Hem biyolojik hem de fizikokimyasal verilerle İyidere deresinin kirlenmediği sonucuna varıldı. Ancak Çiftekavak deresinin kirlilik tehdidi altında olduğu tespit edildi.

Anahtar Kelimeler: Sucul taban büyük omurgasızları, Çiftekavak Deresi, İyidere Deresi, su kalitesi 
DOI: 10.29132/ijpas.398725

\section{INTRODUCTION}

Rivers are ecosystems affected first by environmental pollution. Pollutants originating from domestic, industrial and agricultural activities are firstly involved in rivers (Kara and Çömlekçioğlu, 2004).

Water has been one of the most important natural resources in terms of the continuity of life since the existence of mankind and throughout history has had a decisive influence on many elements such as lifestyles, settlements, living forms of civilization (Özsoy, 2009). As a result of the events that humanity has shown with the purpose of development, the jump that it has caught in scientific, industrial and technological sense has brought some negative results with it. Increasing demand for water with rapid population growth is one of the most important problems that prepare the ground for negative situations such as unconscious consumption and pollution of water in agricultural and industrial areas (Öz et al., 2017). Water is vital to fulfilling important functions such as the production of electrical energy and the discharge of industrial waste, some of the most important needs of our time. However, in recent years; understanding, identifying, taking precautions and finding solutions have gained great importance and speed (Uzun, 2012; Öz et al., 2017). Our country seems to be very rich in terms of fresh water resources like lakes and rivers. But if we do not make efforts to use our resources more efficiently, we will be able to come to a place where there is a water problem in the near future. Excess contamination has been found in some of the existing surface and groundwater waters due to growth of the industrialist, widespread use of fertilizers and medicines in agriculture, and inadequate settlement of environmental awareness. So that some of the surface waters of the basin are polluted water from the $4^{\text {th }}$ degree (Öz et al, 2017).

Although traditional water quality monitoring programs are focused on chemical monitoring, water quality managers are increasingly relying on biological assessments that provide crucial information on ecosystem conditions. While the instantaneous (acute) status determination of the water can be done by chemical analysis of the water quality determination methods, the methods of using the biological elements allow us to have information about the effects of the aquatic habitat (chronic) for a certain period of time depending on the living element being used. The most important advantage of using biological materials to characterize the general state of the water is that they reflect the historical background of the stress sources of a region in a very good way. One of the most widely accepted biological evaluation approaches is the Index of Biotic Integrity (IBI), which is a status indicator and is known as multiple measurement applications (Akkan et al., 2013; Çiçek and Birecikligil, 2015; Verep et al., 2016; Akkan, 2017; Mutlu et al., 2017; Tunç Dede and Sezer, 2017; Verep et al., 2017; Uncumusaoğlu and Akkan, 2017).

While the instantaneous (acute) status determination of the water can be done by chemical analysis of the water quality determination methods, the methods of using the biological elements allow us to have information about the effects of the aquatic habitat (chronic) for a certain period of time depending on the living element being used. The most important advantage of using biological materials to characterize the general state of the water is that they reflect the historical background of the stress sources of a region in a very good way. One of the most widely accepted biological evaluation approaches is the Index of Biotic Integrity (IBI), which is a status indicator and is known as multiple measurement applications (Çiçek and Birecikligil, 2015).

Macroinvertebrates to determine the status of rivers in Turkey use of the Water Framework Directive (WFD) (Directive 2000/60 / CE 2000) has been imposed on the necessity of making it mandatory (Kazanc1 et al., 2010). Due to the physical, chemical and biological contamination of waters, changes in quality and quality of water come into play. These changes affect living creatures in the water (Kara and Çömlekçioğlu, 2004).

In this study, the pollution of İyidere and Çiftekavak Streams in Rize has been evaluated together with physico-chemical and biological factors. As diversity indices, Saprobi Index (SI), Family Biotic Index (FBI), Biological Monitoring Index Scores (BMWP), Belgium Biotic Index (BBI), Avarage Score Per Taxon Index (ASPT) and Ephemeroptera Per Taxon (EPT) taxon number had been used in evaluation.

\section{MATERIAL AND METHOD Study Area}

Rize has been set up north east in Turkey. This city's climate, cool summers, and winters are mild and it has every season rainy climate. Thanks to the rainy climate and the many sources of underground water has a very rich hydrographic structure. There 
DOI: 10.29132/ijpas.398725

are the 23 streams longer than $5 \mathrm{~km}$ in Rize. İyidere stream is all of them the largest with length of 78,4 $\mathrm{km}$. Also it has six large tributary. Çiftekavak Stream is under heavy urban effect. Its long is only $7 \mathrm{~km}$ and it has low flow and discharge (Figure 1).

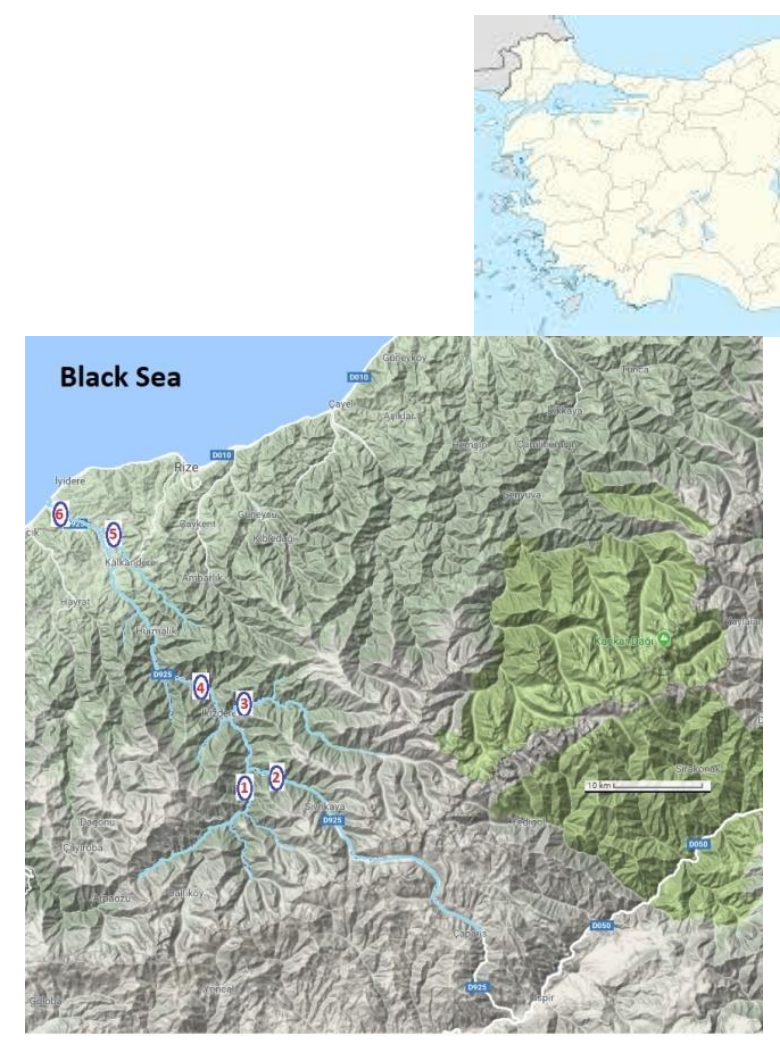

(a)
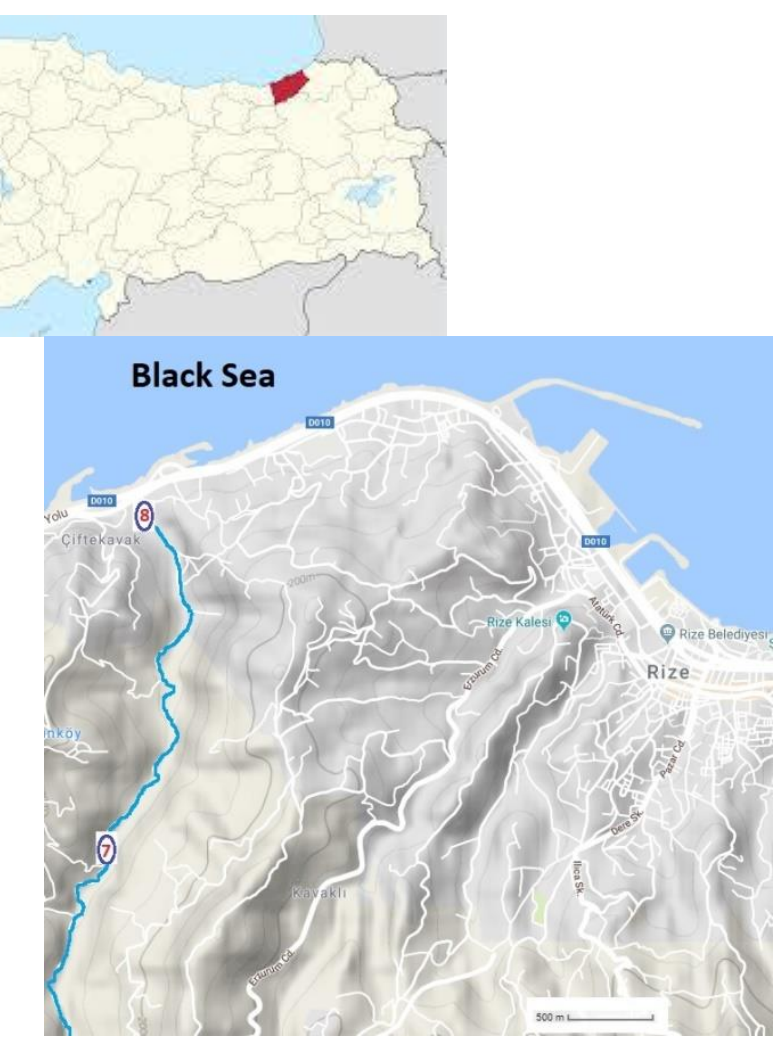

(b)

Figure 1. Study area İyidere Stream (a) and Çiftekavak Stream (b) (URL-1)

Present in this study, the investigation was carried out on the Streams of Çiftekavak and İyidere in Rize between April 2010 and March 2011.
Samples were taken monthly from the station which chosen 6 sample points on İyidere and 2 sample point on Çiftekavak Stream (Table 1).

Table 1. Location of stations

\begin{tabular}{|c|c|c|}
\hline \multicolumn{3}{|c|}{ İyidere Stream Sampling Points, Coordinates and Altitude } \\
\hline 1. Station & 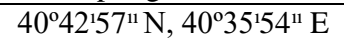 & $960 \mathrm{~m}$ \\
\hline 2. Station & $40^{\circ} 43^{1} 04^{11} \mathrm{~N}, 40^{\circ} 23^{156^{11}} \mathrm{E}$ & $995 \mathrm{~m}$ \\
\hline 3. Station & $40^{\circ} 53^{1} 19^{11} \mathrm{~N}, 40^{\circ} 26^{1} 31^{11} \mathrm{E}$ & $557 \mathrm{~m}$ \\
\hline 4. Station & $40^{\circ} 49^{13} 9^{11} \mathrm{~N}, 40^{\circ} 28^{13} 34^{11} \mathrm{E}$ & $484 \mathrm{~m}$ \\
\hline 5. Station & $40^{\circ} 49^{1} 39^{11} \mathrm{~N}, 40^{\circ} 28^{1} 34^{11} \mathrm{E}$ & $60 \mathrm{~m}$ \\
\hline 6. Station & $40^{\circ} 49^{13} 39^{11} \mathrm{~N}, 40^{\circ} 28^{1} 34^{11} \mathrm{E}$ & $25 \mathrm{~m}$ \\
\hline \multicolumn{3}{|c|}{ Çiftekavak Stream Sampling Points, Coordinates and Altitude } \\
\hline 7. Station & $40^{\circ} 49^{13} 9^{11} \mathrm{~N}, 40^{\circ} 28^{13} 34^{11} \mathrm{E}$ & $45 \mathrm{~m}$ \\
\hline 8. Station & $40^{\circ} 49^{1} 39^{11} \mathrm{~N}, 40^{\circ} 28^{13} 34^{11} \mathrm{E}$ & $1 \mathrm{~m}$ \\
\hline
\end{tabular}

\section{Sample Collection}

Benthic macroinvertebrates were collected by kicking for 3 minutes with 20 replications at 8 sampling sites with a hand net (frame, $30 \mathrm{~cm}$ high and $30 \mathrm{~cm}$ wide) every station (AQEM 2002). Macroinvertebrates were separated from sediments at the laboratory by visual examination and stereomicroscope (Olympus $\mathrm{C} \times 21$ ). The collected material and organisms were preserved in $4 \%$ formaldehyde. Water samples taken up been from same day and same stations point. 
DOI: 10.29132/ijpas.398725

\section{Diversity and biotic indices}

Water quailty was evaluated according to benthic macroinvertebrates. In this study, seven different biotic index such as SI, FBI, BMWP, BBI, ASPT and EPT taxon number were used in evaluation according to benthic macroinvertabrates.

The statistical results of evaluating biotic indexes were obtained using asteric 3.3 package program.

\section{Analysis of Physico-chemical Parameters}

The physico-chemical parameters like biological oxygen demand (BOD), total hardness, magnesium $(\mathrm{Mg})$ and calcium $(\mathrm{Ca})$ were measured by standard titrimetric methods on the day the water samples were taken. Water temperature (T), dissolved oxygen (DO), oxygen saturation, $\mathrm{pH}$, salinity and specific conductivity (EC) were measured in situ with portable instruments (YSI Professional plus). Nitrite nitrogen $\left(\mathrm{NO}_{2}-\mathrm{N}\right)$ and total phosphate $\left(\Sigma \mathrm{PO}_{4}{ }^{3}\right)$ measured spectrophotometric methods.

Statistical analyzes were performed by applying the One Sample T-Test to the SPSS 24.0 package program.

\section{RESULTS}

\section{Physico-chemical Measurements}

The water temperature determined in the surface water of İyidere Stream during one year of study ranges between $0.6{ }^{\circ} \mathrm{C}$ (January) and $27.3^{\circ} \mathrm{C}$ (June). The average value was $11.3{ }^{\circ} \mathrm{C}$. The water temperature determined during the work on the surface of Çiftekavak Deresi ranges from 8.3 (February) to $28.7^{\circ} \mathrm{C}$ (June). The average value was $16.9^{\circ} \mathrm{C}$.

The $\mathrm{pH}$ value determined during the one year study in İyidere surface waters ranged from 7.58 (April) to 9.13 (July). The average value was 8.0. The $\mathrm{pH}$ value determined at the Çiftekavak Stream varies between 7.63 (September) and 8.9 (February). The average value was 8.1 .

The dissolved oxygen amount of the İyidere Stream was determined to be between 7.86 (June) and $14.11 \mathrm{mg} \mathrm{L}^{-1}$ (January) in the a year of study. The mean amount value was determened $11.1 \mathrm{mgL}^{-1}$. The amount of dissolved oxygen in water determined during the study on the surface of the Ciftekavak Stream surface varies from 7.00 (June) to $12.61 \mathrm{mg}$ $\mathrm{L}^{-1}$ (January) . The mean amount value was determened $10.43 \mathrm{mg} \mathrm{L}-1$.

The BOD amount ranged from 0.53 (June) to $8.60 \mathrm{mg} \mathrm{L}^{-1}$ (May) during a year of study in the İyidere Stream. The mean value was $3.23 \mathrm{mg} \mathrm{L}^{-1}$. The BOD amount ranged in the Çiftekavak Stream from 1.20 (July) to $7.15 \mathrm{mg} \mathrm{L}^{-1}$ (December) at the of a year. The mean value was $4.69 \mathrm{mg} \mathrm{L}^{-1}$.

The total hardness determined in the İyidere Stream during a year of study ranged from 15 (May) to $85 \mathrm{mg} \mathrm{L}^{-1}$ (May). The mean amount was $38.32 \mathrm{mg}$ $\mathrm{L}^{-1}$. The total hardness amount of the Çiftekavak Stream was ranged from 36 (February) to $89 \mathrm{mg} \mathrm{L}^{-1}$ (August). The mean value was $72.58 \mathrm{mg} \mathrm{L}^{-1}$.

The nitrite nitrogen amount determined in the İyidere stream during a year of study ranged from 0.00105 (April) to $0.33617 \mu \mathrm{g} \mathrm{L}^{-1}$ (December). The mean value was $0.08358 \mu \mathrm{g} \mathrm{L^{-1 }}$. The nitrite nitrogen amount determined during the study in the Çiftekavak Stream range from 0.00642 (May) to $0.68912 \mu \mathrm{g} \mathrm{L}^{-1}$ (October). The mean amount was $0.16565 \mu \mathrm{g} \mathrm{L}^{-1}$.

The total phosphate amount determined in the surface water of İyidere Stream during a year ranged from 0.00 (December) to $122.89 \mathrm{mg} \mathrm{L}^{-1}$ (May). The mean amount was $3.32 \mathrm{mg} \mathrm{L}^{-1}$. Total phosphate amount in the surface waters of the Çiftekavak Stream ranges from 0.018 (June) to $34.50 \mathrm{mg} \mathrm{L}^{-1}$ (May). The mean value was $7.6 \mathrm{mg} \mathrm{L}^{-1}$.

The mean and standard errors of some physicochemical results of the water quality of the İyidere and Çiftekavak Streams are given in Table 2. 
DOI: 10.29132/ijpas.398725

Table 2. Means of some physico-chemical parameter data belong to İyidere and Çiftekavak Streams

\begin{tabular}{|c|c|c|c|c|c|c|c|c|}
\hline \multirow{2}{*}{ Parameters } & \multicolumn{8}{|c|}{ Stations } \\
\hline & 1 & 2 & 3 & 4 & 5 & 6 & 7 & 8 \\
\hline $\mathrm{T}\left({ }^{\circ} \mathrm{C}\right)$ & $8.60 \pm 5.3$ & $9.04 \pm 4.6$ & $9.96 \pm 5.3$ & $11.09 \pm 5.4$ & $15.80 \pm 6.1$ & $13.15 \pm 5.3$ & $16.80 \pm 6.1$ & $17.05 \pm 6.1$ \\
\hline Salinity (ppt) & $0.04 \pm 0.07$ & $0.04 \pm 0.06$ & $0.03 \pm 0.05$ & $0.06 \pm 0.10$ & $0.07 \pm 0.09$ & $0.06 \pm 0.08$ & $0.08 \pm 0.1$ & $0.08 \pm 0.10$ \\
\hline $\mathrm{pH}$ & $8.00 \pm 0.2$ & $7.84 \pm 0.2$ & $7.79 \pm 0.2$ & $7.81 \pm 0.2$ & $8.20 \pm 0.4$ & $8.15 \pm 0.2$ & $7.96 \pm 0.1$ & $8.18 \pm 0.3$ \\
\hline $\mathrm{DO}\left(\mathrm{mg} \mathrm{L}^{-1}\right)$ & $11.12 \pm 1.4$ & $11.02 \pm 1.2$ & $11.26 \pm 1.4$ & $11.03 \pm 1.2$ & $10.58 \pm 1.4$ & $11.26 \pm 1.7$ & $10.54 \pm 1.5$ & $10.32 \pm 1.3$ \\
\hline Oxygen Sat. \% & $97.53 \pm 4.5$ & $98.33 \pm 5.1$ & $100.78 \pm 6.2$ & $101.04 \pm 6.1$ & $103.68 \pm 9.5$ & $106.39 \pm 10.7$ & $108.19 \pm 12.6$ & $107.29 \pm 9.6$ \\
\hline $\mathrm{EC}\left(\mu \mathrm{S} \mathrm{cm}^{-1}\right)$ & $66.21 \pm 11.0$ & $64.55 \pm 11.1$ & $63.30 \pm 13.4$ & $67.30 \pm 13.4$ & $112.00 \pm 21.2$ & $73.98 \pm 13.9$ & $84.18 \pm 4.9$ & $125.63 \pm 22.6$ \\
\hline S. Solid $\left(\mathrm{mg} \mathrm{L}^{-1}\right)$ & $14.33 \pm 15.4$ & $28.57 \pm 63.7$ & $32.88 \pm 61.8$ & $31.07 \pm 33.5$ & $112.65 \pm 256.7$ & $73.10 \pm 66.5$ & $78.43 \pm 85.3$ & $65.18 \pm 41.5$ \\
\hline$\sum$ Hardness $\mathrm{mg} \mathrm{L}^{-}$ & & & & & & & & \\
\hline 1) & $38.75 \pm 12.1$ & $30.58 \pm 6.0$ & $27.50 \pm 8.4$ & $32.50 \pm 9.9$ & $59.33 \pm 14.4$ & $41.25 \pm 10.1$ & $71.75 \pm 13.5$ & $73.42 \pm 12.6$ \\
\hline $\mathrm{Ca}\left(\mathrm{mg} \mathrm{L}^{-1}\right)$ & $12.83 \pm 5.2$ & $11.37 \pm 3.4$ & $9.27 \pm 3.2$ & $11.19 \pm 3.3$ & $16.50 \pm 5.1$ & $13.51 \pm 3.9$ & $22.63 \pm 4.8$ & $23.69 \pm 5.0$ \\
\hline $\operatorname{Mg}\left(\mathrm{mg} \mathrm{L}^{-1}\right)$ & $5.54 \pm 1.8$ & $4.25 \pm 0.7$ & $3.73 \pm 1.2$ & $4.30 \pm 1.2$ & $9.21 \pm 4.0$ & $5.90 \pm 1.9$ & $11.45 \pm 3.2$ & $11.48 \pm 3.1$ \\
\hline $\mathrm{NO}_{2}-\mathrm{N}\left(\mu_{\mathrm{g} \mathrm{L}}{ }^{-1}\right)$ & $0.081 \pm 0.08$ & $0.059 \pm 0.08$ & $0.066 \pm 0.08$ & $0.110 \pm 0.10$ & $0.088 \pm 0.09$ & $0.097 \pm 0.12$ & $0.10 \pm 0.08$ & $0.21 \pm 0.19$ \\
\hline$\Sigma \mathrm{PO}_{4}^{3}\left(\mu \mathrm{g} \mathrm{L}^{-1}\right)$ & $0.25 \pm 0.3$ & $1.34 \pm 3.8$ & $1.14 \pm 1.8$ & $3.67 \pm 3.1$ & $1.204 \pm 1.5$ & $2.17 \pm 2.9$ & $6.85 \pm 1.4$ & $8.31 \pm 10.2$ \\
\hline BO D $\left(\mathrm{mg} \mathrm{L}^{-1}\right)$ & $3.30 \pm 2.4$ & $2.99 \pm 1.7$ & $3.29 \pm 2.2$ & $2.94 \pm 1.4$ & $3.45 \pm 1.6$ & $3.41 \pm 1.5$ & $4.72 \pm 2.0$ & $4.66 \pm 1.9$ \\
\hline
\end{tabular}

Table 3. Determination of water quality class and annual mean values of water quality classes according to surface water quality criteria of stations

\begin{tabular}{|c|c|c|c|c|c|c|c|c|}
\hline \multirow{3}{*}{ Water Quality Parameters } & \multicolumn{8}{|c|}{ Stations } \\
\hline & 1 & 2 & 3 & 4 & 5 & 6 & 7 & 8 \\
\hline & \multicolumn{8}{|c|}{ Water Quality Classes } \\
\hline Water Temperature $\left({ }^{\circ} \mathrm{C}\right)$ & I & I & I & I & $\mathrm{I}$ & $\mathrm{I}$ & $\mathrm{I}$ & I \\
\hline $\mathrm{pH}$ & I & $\mathrm{I}$ & I & I & I & I & I & I \\
\hline Dissolved Oxygen $\left(\mathrm{mg} \mathrm{L}^{-1}\right)$ & I & I & I & I & I & I & I & I \\
\hline Oxygen Saturation (\%) & $\mathrm{I}$ & $\mathrm{I}$ & I & $\mathrm{I}$ & I & $\mathrm{I}$ & $\mathrm{I}$ & I \\
\hline Nitrite-Nitrogen $\left(\mathrm{mg} \mathrm{NO}_{2}^{-}-\mathrm{N} \mathrm{L}^{-1}\right)$ & $\mathrm{I}$ & $\mathrm{I}$ & $\mathrm{I}$ & II & II & III & III & IV \\
\hline Total Phosphorus $\left(\mu \mathrm{g} \mathrm{P} \mathrm{L}^{-1}\right)$ & I & I & I & IV & III & III & $\mathrm{I}$ & IV \\
\hline Total solved $\left(\mathrm{mg} \mathrm{L}^{-1}\right)$ & I & I & I & I & I & I & $\mathrm{I}$ & I \\
\hline $\mathrm{BOD}\left(\mathrm{mg} \mathrm{L}^{-1}\right)$ & II & II & II & II & II & II & II & II \\
\hline
\end{tabular}

According to the Water Pollution Control Regulation, continental water resources have been assessed in four quality classes (Class I (High Quality Water), Class II (Less Contaminated Water), Class III (Contaminated Water) and Class IV (Heavy Contaminant)) using physico-chemical data. In the study, physico-chemical measurements were evaluated separately of parameters for all stations (Table 3).

The station 1 (İyidere Stream) physico-chemical data indicate that water quality is water of Class I (High quality) water quality, The station 2 (İyidere Stream) physico-chemical data of the station indicate that water quality has Class I water quality, The station 3 (İyidere Stream) physico-chemical data of the station indicate that water quality has Class I water quality, the station 4 (Iyidere Stream) the physico-chemical data showed that the water quality class was contaminated at theorganically critical level, The station 5 (İyidere Stream) physico-chemical data showed that the water quality class was contaminated at the organically critical level, The station 6 (İyidere Stream) physico-chemical data of the station indicate that water quality has Class II water quality, The station 7 (Çiftekavak Stream) physico-chemical data showed that the water quality class was contaminated at the nutrient element level. The station 8, Çiftekavak Stream in terms of one-year study of the station results in physico-chemical parameters are heavily soiled (Class IV) was determined to be. 
DOI: 10.29132/ijpas.398725

\section{Biotic Index Measurements}

In this study, total of 27 taxa belonging to the groups of Ephemeroptera, Amphipoda, Tricladida, Coleoptera, Decapoda, Rhynchobdellida, Odonata, Diptera, Trichoptera, Plecoptera, Tubificida and
Arthropoda large invertebrate individuals collected from the sampling points were diagnosed (Figure 2).

The diversity index was calculated by asteric software counting the large invertebrate organisms collected from the stations identified (Table 4).

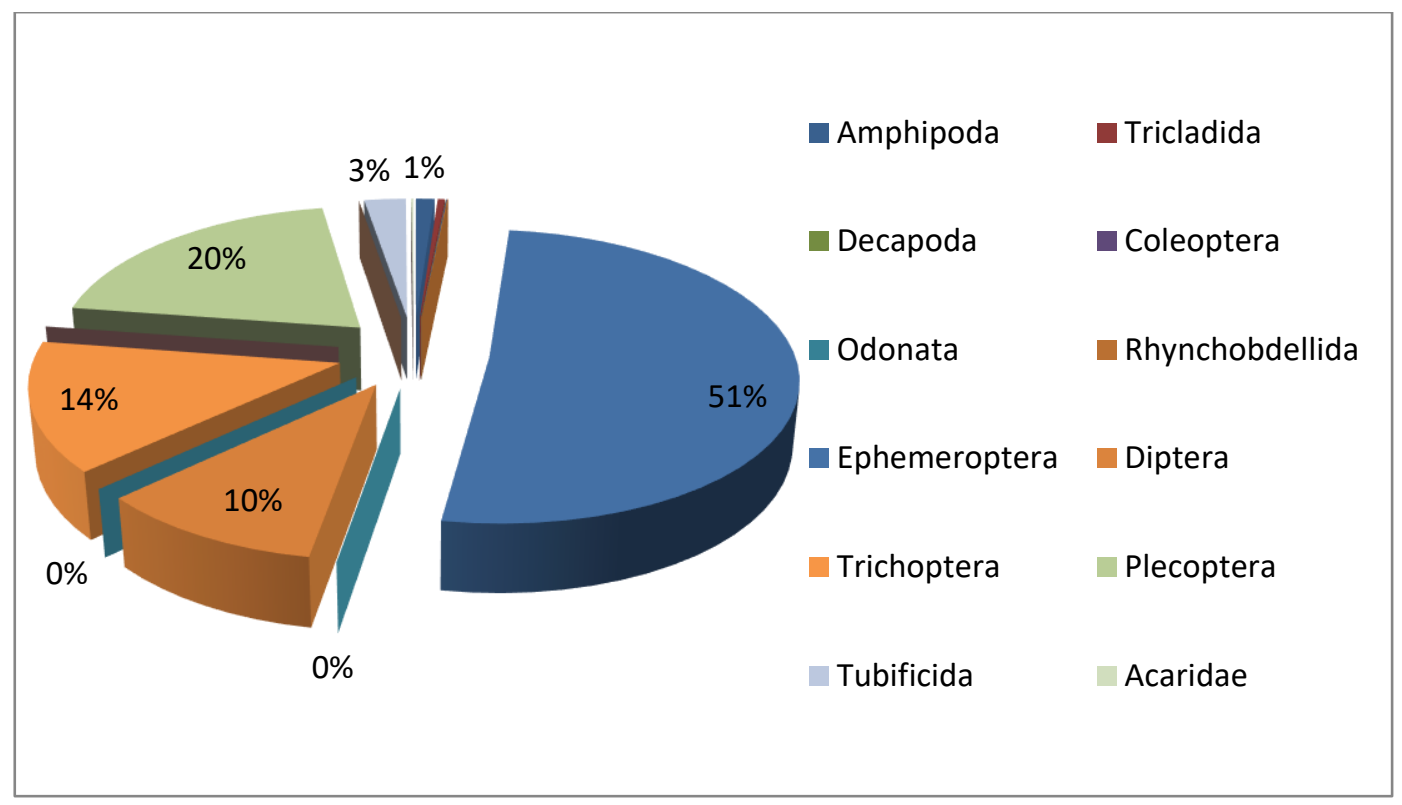

Figure 2. Percentage of collected individuals

Table 4. Diversity indexes by stations

\begin{tabular}{lcccccccr}
\hline & \multicolumn{10}{c}{ Stations } \\
\cline { 2 - 9 } Months & 1 & 2 & 3 & 4 & 5 & 6 & 7 & 8 \\
\hline April & 0.25 & 0.41 & 0.54 & 0.44 & 0.29 & 1.30 & 0.26 & 0.25 \\
\hline May & 0.30 & 0.39 & 0.72 & 0.82 & 0.60 & 2.14 & 0.11 & 1.81 \\
\hline June & 0.38 & 0.49 & 0.71 & 0.54 & 0.51 & 2.60 & 0.49 & 2.72 \\
\hline July & 0.37 & 0.14 & 0.36 & 0.76 & 0.59 & 2.99 & 1.62 & 4.28 \\
\hline August & 0.29 & 0.45 & 0.59 & 0.49 & 1.05 & 2.30 & 0.68 & 4.28 \\
\hline September & 0.23 & 0.28 & 0.50 & 0.42 & 0.58 & 0.97 & 0.58 & 11.97 \\
\hline October & 0.35 & 0.31 & 0.48 & 1.03 & 0.68 & 3.74 & 0.38 & 4.61 \\
\hline November & 0.41 & 0.22 & 0.53 & 1.22 & 0.48 & 1.58 & 0.51 & 2.71 \\
\hline December & 0.15 & 0.17 & 0.17 & 0.37 & 0.60 & 1.93 & 0.89 & 14.97 \\
\hline January & 0.11 & 0.27 & 0.19 & 0.79 & 0.52 & 2.60 & 0.30 & 1.25 \\
\hline February & 0.08 & 0.11 & 0.17 & 0.62 & 0.24 & 0.71 & 0.31 & 2.72 \\
\hline March & 0.13 & 0.10 & 0.12 & 0.31 & 0.11 & 0.28 & 0.11 & 2.30 \\
\hline
\end{tabular}

A similarity table between the stations was established by applying the Sorenson Similarity Index to the data obtained from the study areas. The stations with the most similarity according to the obtained data are I and II. (0.66). The stations 1, 2 and $3^{\text {th }}$ have shown to station 8 the lowest similarities $(0,12)$ (Table 5).
Distribution of the identified organisms by stations was shown in Table 3. Total of 12551 individuals were collected from all stations. The 11 individuals surveyed were diagnosed in 27 taxa (Table 6). 
DOI: 10.29132/ijpas.398725

Table 5. Similarity index between stations in the study area

\begin{tabular}{rrrrllllc}
\hline Stations & 1 & 2 & 3 & 4 & 5 & 6 & 7 & 8 \\
\hline 1 & $\mathbf{1}$ & $\mathbf{0 . 6 6}$ & 0.64 & 0.59 & 0.53 & 0.34 & 0.48 & $\mathbf{0 . 1 2}$ \\
\hline 2 & & $\mathbf{1}$ & 0.64 & 0.60 & 0.54 & 0.21 & 0.31 & $\mathbf{0 . 1 2}$ \\
\hline 3 & & & $\mathbf{1}$ & 0.61 & 0.54 & 0.35 & 0.51 & $\mathbf{0 . 1 2}$ \\
\hline 4 & & & & $\mathbf{1}$ & 0.56 & 0.41 & 0.45 & 0.14 \\
\hline 5 & & & & & $\mathbf{1}$ & 0.44 & 0.50 & 0.16 \\
\hline 6 & & & & & & $\mathbf{1}$ & 0.45 & 0.23 \\
\hline 7 & & & & & & & $\mathbf{1}$ & 0.48 \\
\hline 8 & & & & & & & & $\mathbf{1}$ \\
\hline
\end{tabular}

Table 6. According stations distribution of benthic macroinvertebrates taxons

\begin{tabular}{|c|c|c|c|c|c|c|c|c|}
\hline \multirow[b]{2}{*}{ Groups of taxa } & \multicolumn{8}{|c|}{ Stations } \\
\hline & 1 & 2 & 3 & 4 & 5 & 6 & 7 & 8 \\
\hline Gammarus sp. & $x$ & $x$ & $x$ & & $x$ & & $x$ & \\
\hline Planaria sp. & $x$ & $x$ & $\times$ & $x$ & & & & \\
\hline Potamon sp. & & & & & & & $x$ & \\
\hline Agabus sp. & $x$ & $x$ & & & & & & \\
\hline Onychogomphus forcipatus & & & & & & $x$ & $x$ & \\
\hline Helobdella stagnalis & $x$ & & $\times$ & & & & $x$ & \\
\hline Ephemerella sp. & $x$ & $x$ & $x$ & $x$ & $x$ & $x$ & $x$ & \\
\hline Epeorus sp. & $x$ & $x$ & $x$ & $x$ & $x$ & $x$ & $x$ & \\
\hline Baetis sp. & $x$ & $x$ & $x$ & $x$ & $\times$ & $x$ & $x$ & $x$ \\
\hline Baetis rhodani & $x$ & $x$ & $x$ & $x$ & $x$ & & $x$ & \\
\hline Iron $\mathrm{sp}$. & $x$ & $x$ & $x$ & $x$ & $x$ & & $x$ & \\
\hline Tipula sp. & $x$ & $x$ & $\times$ & $x$ & $x$ & & $x$ & \\
\hline Chironomidae & $x$ & $x$ & $\times$ & $\times$ & $\times$ & $\times$ & & $\times$ \\
\hline Atherix sp. & $x$ & $x$ & $x$ & $x$ & & & $x$ & \\
\hline Dicranota sp. & $x$ & $x$ & $x$ & $x$ & & & & \\
\hline Tabanus sp. & $x$ & $x$ & $x$ & $\times$ & $\times$ & & & \\
\hline Simulium sp. & $x$ & $x$ & $x$ & $x$ & & & & \\
\hline Hydropsyche sp. & $x$ & $x$ & $\times$ & $x$ & $\times$ & $x$ & $x$ & \\
\hline Lepidostoma sp. & $x$ & $x$ & $x$ & $x$ & $\times$ & $x$ & $x$ & \\
\hline Rhyacophila sp. & $x$ & $x$ & $x$ & $x$ & $x$ & & $x$ & \\
\hline Perla sp. & $x$ & $x$ & $\times$ & $\times$ & $\times$ & $\times$ & $x$ & \\
\hline Leuctra sp. & $x$ & $x$ & $\times$ & $x$ & $\times$ & $x$ & $x$ & \\
\hline Isoperla sp. & $x$ & $x$ & $x$ & $x$ & $x$ & & & \\
\hline Protonemura sp. & $x$ & $x$ & $x$ & $x$ & $x$ & $x$ & & \\
\hline Eiseniella sp. & & & & & & & $x$ & \\
\hline Tubifex sp. & $x$ & $x$ & $x$ & $x$ & $\times$ & $x$ & $x$ & $x$ \\
\hline Acariformes & $x$ & $x$ & $x$ & & & & $x$ & \\
\hline
\end{tabular}

The data obtained with the Asterics software are shown in Table 7: SI, FBI, BMWP, ASPT, BBI, TBI,
EPT, and water quality classes of the stations belonging to İyidere and Çiftekavak were determined. 
DOI: 10.29132/ijpas.398725

Table 7. Evaluation of water quality classes of stations determined according to biological classification

\begin{tabular}{lcccccccc}
\hline \multicolumn{1}{c}{ Indexes } & & \multicolumn{7}{c}{ Stations } \\
& 1 & 2 & 3 & 4 & 5 & 6 & 7 & 8 \\
\hline SI & II & II & II & II & II & II & II & II \\
FBI & I & I & I & I-II & I-II & III & II & III-IV \\
BMWP & II & II & II & II & II & III & II & V \\
ASPT & I & I & I & I & I & I & I & III \\
BBI & I & I & I & I & I & I & I & IV \\
TBI & 14 & 14 & 13 & 8 & 7 & 6 & 7 & 4 \\
EPT & 12 & 12 & 12 & 12 & 12 & 10 & 12 & 1 \\
\hline
\end{tabular}

\section{Comparison of Physico-Chemical and Biotic Indexes Data}

Examination biologically of the 1. Station (İyidere Stream), it was determined to as slightly contaminated (Class II) according to SI. Similarly according to ASP (Class I), and slightly was contaminated according to BBI (Class I) (Table 7).

Examination biologically of the 2. Station (İyidere Stream), it has been determined that Class II for SI, there was no pollution (Class I) for FBI , very little dirty (Class II) for BMWP, Class I for ASPT and slightly uncontaminated (Class I) for BBI (Table 7).

Examination biologically of the 3. Station (İyidere Stream), it has been determined that Class II for SI , there was no pollution (Class I) for FBI , very little dirty (Class II) for BMWP, Class I for ASPT and slightly uncontaminated (Class I) for BBI (Table 7).

Examination biologically of the 4. Station (İyidere Stream), it has been determined that Class II for SI, slightly contaminated (Class II) for FBI, very little dirty (Class II) for BMWP, Class I for ASPT and slightly uncontaminated (Class I) for BBI (Table 7).

Examination biologically of the 5. Station (İyidere Stream), it has been determined that Class II for SI, slightly contaminated (Class II) for FBI, very little dirty (Class II) for BMWP, Class I for ASPT and slightly uncontaminated (Class I) for BBI (Table 7).

Examination biologically of the 6. Station (İyidere Stream), it has been determined that Class II for SI, highly polluted (Class III) for FBI, little dirty (Class III) for BMWP, Class I for ASPT and slightly uncontaminated (Class I) for BBI (Table 7).

Examination biologically of the 7. Station (Çiftekavak Stream), it has been determined that Class II for SI, slightly contaminated (Class II) for

FBI, very little dirty (Class II) for BMWP, Class I for ASPT and slightly uncontaminated (Class I) for BBI (Table 7).
The 8. station, Çiftekavak Stream in terms of one-year study of the station results in according to physico-chemical parameters are heavily soiled (Class IV) was determined to be. Biologically, it has been determined that Class II for SI, very polluted (Class III-IV) for FBI, contaminated (Class IV) for BMWP, dirty in the middle (Class III) for ASPT and heavily polluted (Class IV) for BBI (Table 7).

\section{DISCUSSION}

Girgin 2010 reported the most common taxon as Ephemeroptera in Keşap Stream. It was also reported that Potamanthus, Baetis and Ephemerella genuses belonging to this clade dominated. In addition, it was said that the water quality of the areas in the summer season was slightly or slightly contaminated outside station 6. Station 6 had heavy pollution. In particular, water quality in stream areas (sampling areas 2, 4, 6) after industrial facilities has decreased. However, according to the biotic index values, very heavy pollution was not observed.

Kazanc1 et al. 2010, reported that the Aksu Stream could be evaluated by the methods of the European Union Water Framework Directive to determine water quality using bimodal macroinvertebrate based multi-criteria indices. Also showed that these methods could be used to classify reference sites in Aksu Stream. In their study, they provided evidence that the social structure of benthic macroinvertebrates changed throughout Aksu Stream because of the decrease in habitat quality. In the lower part of the Aksu Stream, urbanization, tourism, seasonal housing, agricultural activities and the physical condition of the river bed, are considered as the reasons for lower habitat quality.

This study, in the biological and physicochemical analyzes of the İyidere Stream, the quality of the stream was determined to be of Class I uncontaminated water quality. The high amount of total phosphate and nitrogen compounds in spring 
DOI: 10.29132/ijpas.398725

have led to the conclusion that fertilization for regional agriculture may be the end. Only in the 8th station it was determined that there are fewer taxon numbers in terms of biological indices. This station is closest to sea level. According to Vannote 1980, noted that the study of the distribution of living creatures in the river (The River Concept) showed that biological diversity decreased at points where the stream merged with the sea.

The biological and physico-chemical analyzes of the Çiftekavak Stream indicate that the quality of the stream was very different in the two stations. The 7 . station the water quality was not affected by the city. In the summer periods, in terms of nitrogen compounds and total phosphate, class. According to other physico-chemical parameters and according to the result of biological data, water quality class was determined as Class I. It has been determined that the other station (Station8) of the Çiftekavak Stream is under intensive pollution hazard in the analysis of biological data, both physico-chemical. It can be said that the reasons for this are the wastes discharged to the river, the water supply of the river is too low to dispose of these wastes, and it is not able to remove the effects of domestic and small scale industrial structures.

Mutlu et al. (2017), in their study, they investigated physicochemical water quality criteria and water pollution parameters of Sarayköy, Derepazarı, Çiftekavak, Taşlıdere Streams. As a result, the waters of the Sarayköy, Derepazar1, Çiftekavak, Taşlidere Streams, physical and some physicochemical factors. Class 1: It can be named as high quality water and it can be considered that the nutrients that the rivers carry are considered to be less polluted by inorganic nitrogen. It is understood that there are some problems in respect of carp breeding in terms of aquaculture. The waters of these streams are therefore suitable for drinking water standards; only reported disinfection and drinking water supply, recreational purposes (including those requiring body contact such as swimming), water booms that can be evaluated for trout production, animal production and farming needs and other similar purposes.

Verep et al. 2005, in their study, in the water analyzes conducted in İyidere Stream which has a good water quality with no significant problem in terms of water pollution, it has been found that some mineral salts are insufficient in terms of fish breeding. In general, this situation, which does not present a danger to aquatic life and fish life, needs to be taken into consideration when using water for fish breeding. The use of rich fish feeds in terms of mineral salts, lime or other additives have been found to eliminate this deficiency and report that fish cultivation can be carried out efficiently in the İyidere Streams.

Verep et al. 2016, in their study according to the results of the study they have done, they reported that there is no significant difference in the statistical significance except the ammonium nitrogen when the effect level of the water resources within the tea cultivation areas and the forest areas are examined. While there is a significant difference between ammonium and forest area of 3.7 times in terms of ammonium, this difference is about $12-13 \%$ in terms of nitrite and phosphate. According to these results, they reported that fertilizing effect in tea agriculture activity is important values for surface water resources.

In this study presented, in the biological and physico-chemical analyzes of the İyidere Stream, the quality of the stream was determined to be of Class I uncontaminated water quality. The high amount of ortho-phosphate and nitrogen compounds in spring have led to the conclusion that fertilization for regional agriculture may be the end. It has been observed that the construction of the İyidere stream has increased. In addition, it is assumed that the construction of hydroelectric power plant (HPP) continues to be a reference work in terms of how the quality of water will be affected in the future. If İyidere's waters are evaluated according to the intercontinental water quality standards declared in the Water Pollution Control Regulation No. 25687, it is seen that it is a water source with Class I (Very clean) water quality standard. It can be said that İyidere Stream waters are the only source of water that can be used for disinfection, drinking water supply, recreational purposes (including those requiring body contact such as swimming), animal production and farming needs and other purposes.

The biological and physico-chemical analyzes of the Çiftekavak Stream indicate that the quality of the stream is very different in the two stations. It can be said that the 7th station water quality of the Çiftekavak Stream located near the city is not affected by urban waste. In the summer periods, in terms of nitrogen compounds and total phosphate, class I. According to other physico-chemical parameters and according to the result of biological data, water quality class was determined as Class I. It has been determined that the other station (VIII. Station) of the 
DOI: 10.29132/ijpas.398725

Çiftekavak Stream pile is under intensive pollution hazard in the analysis of biological data, both physico-chemical. It can be said that the reasons for this are the wastes discharged to the river, the water of the river is too low to flow of these wastes, and it is not able to remove the effects of small scale industrial structures. The area forming this station is under anthropogenic influences left by channels along both sides. In addition, it is possible that all kinds of wastes of the small-scale industrial site, which is under construction, are untreated from this stream discharge.

Also, tea production is being carried out as an agricultural activity in the Rize. Nitrogen, phosphate and potassium supplements called NPK are given as fertilizers in tea cultivation. It has been determined that the total phosphate amount peaked during the month of March due to the start of the fertilization season of tea fields at the end of March and the process of mixing fertilization with dissolved surface waters in June.

\section{ACKNOWLEDGEMENTS}

This master thesis study has been supported by Recep Tayyip Erdoğan University of Scientific Study Project with code of 2011.103.01.1. This study had been presented in the conference on Deutsche Gesellschaft für Limnologie (DGL), At Koblenz and published as summary in the proceedings.

\section{REFERENCES}

Akkan, T. 2017. An Assessment of linear Alkylbenzene Sulfonate (Las) pollution in Harsit stream, Giresun, Turkey, Fresenius Environmental Bulletin, 26(5): 3217-3221.

Akkan, T., Kaya, A., Dinçer, S. 2013. Antibiotic levels and heavy metal resistance in gram-negative bacteria 1solated from seawater, Iskenderun Organized Industrial Zone, Journal of Applied Biological Sciences, 1: 10-14.

AQEM Consortium. 2002. Manual for the application of the AQEM system. A comprehensive method to assess European streams using benthic macroinvertebrates, developed for the purpose of the Water Framework Directive. Version, 1.

Çiçek, E., Birecikligil, S. 2015. Yüzeysel sularda su kalitesinin değerlendirmesi ve izlenmesi için biyolojik bütünlük indeksi: balık indekslerinin kullanılması. Nevşehir Bilim ve Teknoloji Dergisi, 4(1): 45. https://doi.org/10.17100/nevbiltek.38520

Girgin, S. 2010. Evaluation of the benthic macroinvertebrate distribution in a stream environment during summer using biotic index. International Journal of Environmental Science \& Technology, 7(1): 11-16.

Kara, C., Çömlekçioğlu, U. 2004. Karaçay (Kahramanmaraş)'ın kirliliğinin biyolojik ve fiziko-kimyasal parametrelerle incelenmesi. $K S U$ Journal of Science and Engineering, 7(1): 1-7.

Kazancı, N., Ekingen, P., Türkmen, G., Ertunç, Ö., Dügel, M., Gültutan, Y. 2010. Assessment of ecological quality of Aksu Stream (Giresun, Turkey) in Eastern Black Sea Region by using water framework directive (WFD) methods based on benthic macroinvertebrates. Review of Hydrobiology, 3(2):165-184.

Mutlu, T., Verep, B., Onay D., Kırlığlu K., 2017. Physico-Chemical water quality of some streams flowing to the Southeastern Black Sea. Journal of Anatolian Environmental\&Animal Sciences 2(3):67-71

Öz, Ü., Ertaş, E., Aral, O. 2017. Evaluation of Arılı stream (Rize) water for aquaculture. Gaziosmanpasa Journal of Scientific Research, 6(2):1-10.

Özsoy, S., 2009. Su ve yaşam: Suyun toplumsal önemi. Yüksek Lisans Tezi, T.C. Ankara Üniversitesi, Sosyal Bilimler Enstitüsü, Çalışma Ekonomisi ve Endüstri İlişkileri Anabilim Dalı, Ankara.

Tunç Dede, Ö. and Sezer, M. 2017. Aksu çayı su kalitesinin belirlenmesinde Kanada su kalitesi indeks (CWQI) modelinin uygulanmas1. Journal of the Faculty of Engineering and Architecture of Gazi University, 32(3):909-917.

Uncumusaoğlu, A.A. and Akkan, T. 2017. Assessment of water quality of Yağlidere stream (Turkey) using multivariate statistical techniquess, Polish Journal of Environmental Studies, 26(4):17151723.

URL-1

https://www.google.com.tr/maps/@ 40.9682521,4 $0.4383098,11138 \mathrm{~m} / \mathrm{data}=! 3 \mathrm{~m} 1 ! 1 \mathrm{e} 3 \mathrm{hl}=\mathrm{tr} \quad 06$ Ocak 2018,12:45

Uzun, H.í., 2012. Riva deresi su kalitesinin belirlenmesi ve istatistiksel analizi. Yüksek Lisans Tezi, Sakarya Üniversitesi, Fen bilimleri Enstitüsü, Çevre Mühendisliği Ana Bilim Dalı, Sakarya.

Vannote, R.L., Minshall, G.W., Cummins K.W., Sedell, J.R., Cushing, C.E., 1980. The River Continuum Concept. Can J. Fish. Aquat. Sci. 37:130-137.

Verep, B., Mutlu, T., Çakir, V., Aydin, G., 2017. Determination of physico-chemical water quality of derepazarı stream and evaluation according to some water quality standards, Journal of Anatolian Environmental and Animal Sciences, 2(1):19-22.

Verep, B., Ödün Akçanal, N., 2016. Çay tarımında kullanılan suni ve doğal gübrelerin Fırtına vadisi 
DOI: 10.29132/ijpas.398725

(Çamlıhemşin-Rize) Behice deresinin Fizikokimyasal su kalitesine etkisi, Anadolu Çevre ve Hayvancllik Bilimleri Dergisi, 1(1):1-13.

Verep, B., Serdar, O., Turan, D., Şahin, C., 2005. İyidere (Trabzon)'nin fiziko-kimyasal açıdan su kalitesinin belirlenmesi, Ekoloji 14(57):26-35. 